Volume 02 Nomor 012020 : page 16-33

p-ISSN: 2686-262X e-ISSN : 2685-9300

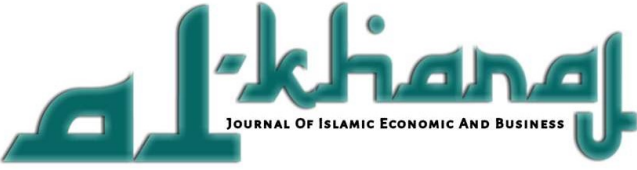

DOI : 10.24256

\title{
Pengaruh Promosi Dan Kualitas Pelayanan Terhadap Minat Menabung Masyarakat Kelurahan Siranindi Di Bank Muamalat Indonesia Palu Sulawesi Tengah
}

\author{
Sitti Aisya ${ }^{1)}$ dan Yohansyah Adiputra Riyadi ${ }^{2)}$ \\ 1) \& 2) FEBI IAIN Palu \\ email: majhafaisyah@yahoo.com
}

\begin{abstract}
Abstrak
Eksistensi BMI di kancah industri perbankan masih bertahan walaupun terdapat kompetitor yang telah dibentuk pemerintah maupun yang dibentuk oleh korporate perusahaan besar, sehingga keberadaannya masih dapat diperhitungkan. Namun promosi dan fasilitas kompetitornya, BMI sedikit lebih kecil dibandingkan lainnya. Oleh karena itu, tujuan penelitian ini adalah untuk mengetahui pengaruh promosi dan kualitas pelayanan terhadap minat menabung masyarakat. Lebih lanjut metode penelitian dilakukan dengan observasi, penyebaran kuesioner dan wawancara. Selanjutnya dilakukan pengolah data dengan analisis asumsi klasik, regresi berganda dan uji hipotesis. Hasilnya bahwa promosi tidak berpengaruh signifikan terhadap minat menabung masyarakat di BMI, sebaliknya kualitas pelayanan berpengaruh signifikan secara parsial terhadap minat menabung di BMI. Namun bila keduanya secara simultan berpengaruh signifikan terhadap minat menabung masyarakat. Hal ini terjadi karena kurangnya promosi yag dilakukan BMI terhadap masyarakat. Kualitas layanan oleh BMI dapat dilarasakan lansung oleh masyarakat.
\end{abstract}

\section{Keywords: Promosi, Kualitas Layanan, Minat Menabung}

\section{Pendahuluan}

Bank Muamalat Indonesia merupakan bank pertama yang didirikan berdasarkan sistem bagi hasil. Bank ini awalnya bernama Bank Muamalat dan dibentuk atas inisiasi presiden BJ. Habibi selaku ketua ICMI waktu itu untuk mendirikan bank berbasis syariah dan menjawab permasalahan masyarakat atas berbagai pendapat alim ulama yang mengkategorikan bunga bank termasuk riba.

Persoalan riba di kalangan umat Islam, salah satu bentuk transaksi yang harus dihindari dan ditinggalkan karena riba termasuk bentuk transaksi yang diharamkan oleh Allah swt. sebagaimana firman Allah swt. dalam Q.S. al-Baqarah (2): 275 yang artinya “...Allah telah menghalalkan jualbeli dan mengharamkan riba". Konsekuensi yang 
Volume 02 Nomor 012020 : page 16-33

p-ISSN: 2686-262X e-ISSN : 2685-9300

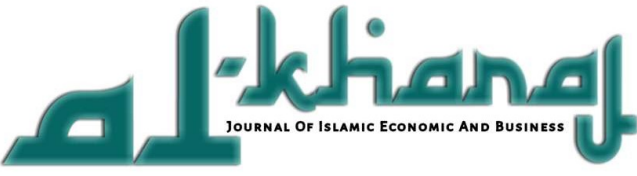

DOI : 10.24256

mengomsumsi riba, dalam Qs. an-Nisaa (4) : 161 Allah dan Rasulnya akan memeranginya dan akan memberi siksaan yang sangat pedih.. Pijakan inilah yang melatarbelakangi mendesak pembentukan lembaga keuangan berbasis syariah di Indonesia..

Perjalanan panjang yang dilalui Bank Muamalat Palu menguji eksistensinya sebagai bank pertama murni syariah. Namun gaungnya terdengar redup dengan munculnya bankbank syariah lainnya baik bank berinduk konvensional maupun bank berbasis syariah, terlebih permasalahan internal bank Muamalat itu sendiri seperti masalah suntikan dana yang tak kunjung selesai, kurangnya kantor cabang/unit, sulitnya akses transaksi ATM Khusus Muamalat, kurangnya informasi tentang bank bersangkutan dan lain-lain.

Faktor internal dan ekternal tersebut tentu berdampak terhadap minat masyarakat untuk menabung atau melakukan pembiayaan dari perbankan. Khususnya minat menabug masyarakat (calon nasabah) yang merupakan sisi kejiwaan yang menyebabkan untuk tertarik menempatkan materi (uang) di bank. Faktor inilah yang menentukan dalam menilai minat masyarakat. Bank Syariah dapat melakukan strategi dalam mempromosikam produknya sebagai pengenalan dan pengetahuan kepada masyarakat untuk bertransaksi dengan setidaknya menabung di bank syariah.

Promosilah merupakan sarana yang paling ampuh untuk menarik dan mempertahankan nasabahnya karena selain menginformasikan produk juga berfungsi utuk mengingatkan nasabah maupun calon nasabah akan produk yag ditawarkan. Selain promosi, fasilitas juga memberi andil dalam menarik calon nasabah menabung di bank. Kenyamanan kantor, kemudahan transaksi misalnya taransfer antar bank, memudahkan menabung dan menarik baik manual maupun melalui sarana ATM (Anjugan Tunai Mandiri) atau aplikasi e-mobile banking, serta fasilitas pendukung lainnya.

Faktor terpenting yang juga menarik minat menabung yakni kualitas pelayanan yang menyempurnakan atas fasilitas yang dimiliki oleh bank. Parasuraman menganggap bahwa 
Volume 02 Nomor 012020 : page 16-33

p-ISSN: 2686-262X e-ISSN : 2685-9300

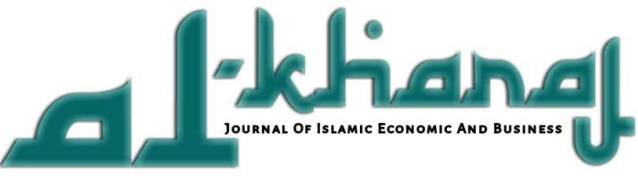

DOI : 10.24256

nasabah selalu menilai layanan yang diterima dibandingkan dengan apa yang diharapkan atau yang diinginkan (Rachmat Hidayat, 2009:59). Oleh karena itu, pelayanan yang berkualitas yang diterima masyarakat sangat berpengaruh terhadap keputusan untuk menabung materi (uangnya) di bank bersangkutan.

Hal lain yang punya andil dalam menentukan calon nasabah menurut Bambang Haryo Nugroho selaku Kancab BMI Palu, bahwa minat menabung calon nasabah dapat ditentukan dari kondisi suatu wilayah atau karakter masyarakat yang dituju sebagai objek market share bank. Objek khusus Kelurahan Siranindi memiliki karakteristik yang khas. Kelurahan Siranindi terkenal dengan lingkungan yang tinggi nilai religiusitasnya dengan eksistensi kawasan religi Sis al-Jufri salah satu nama ulama penyebar agama Islam dan pendiri pesantren Al-Khairat di Palu Sulawesi Tengah. Khas tersebut menjadikan bank Muamalat membidik masyarakat sebagai objek pangsa pasar dengan melakukan berbagai promosi, menyediakan fasilitas lengkap dan menawarkan konsep kualitas pelayanan yang kan diberikan guna menarik masyarakat untuk menjadi nasabah bank Muamalat. Identifikasi masalah penelitian ini ditemukan dalam observasi kurangnya promosi yang dilakukan dalam menarik nasabah. Demikian halnya kualitas pelayanan masih perlu ditingkatkan apabila dibadingkan dengan kompetitornya, namun jumlah nasabah tetap terjadi peningkatan setiap tahunnya. Oleh karena itu, apakah promosi dan kualitas nelayan berpengaruh signifikan terhadap minat menabung masyarakat di Bank Muamalat secara parsial maupun simultan?

\section{Tinjauan Pustaka}

Bank Muamalat Indonesia Tbk. (BMI) memulai prjalanan bisnisnya sebagai bank syariah pertama di indonesi pada 1 November 1991 atau 24 Rabiul Akhir 1412 H. Pendirian BMI digagas oleh Majelis Ulama indoesia (MUI), Ikatan Cendekiawan Muslim Indoesia 
Volume 02 Nomor 012020 : page 16-33

p-ISSN: 2686-262X e-ISSN : 2685-9300

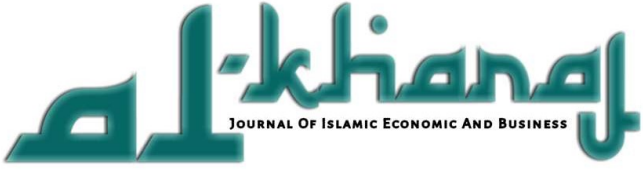

DOI : 10.24256

(ICMI) dan Pengusaha Muslim yang kemudian mendapat dukungan dari pemerintah

Republik Indonesia. Sejak beroperai 1 Mei 1999, BMI terus berinovasi dalm diversifikai produk jasa yag ditawarkankan ke masyarakat antara lain Dana Pensiun Lembaga Keuangan Muamalat (DPLK) dan Multifinance Syarah (al-Ijarah Indonesia Finance) yang seluruhnya menjadi terobosan di dunia perbankan. Selain itu, sebelumnya Shar'e produk BMI yang diluncurkan pada tahun 2004 merupakan tabungan instan pertama terutama adanya layanan e-channel seperti internet banking, mobile banking, ATM dan cash management.

Dengan visi menjadi bank syariah terbaik dan termasuk dalam 10 besar bank di Indonesia dengan eksitensi yang diakui di tingkat regional. BMI menumbuhkan keuangannya dengan terdapatnya beberapa kantor cabang diberbagai wilayah di kota propinsi maupun kota kabupaten. Salah satunya di Propinsi Sulawesi Tengah khususnya di kelurahan Siranindi. Bank Muamalat Indonesia sendiri memiliki tiga kantor cabang utama dan dua kantor cabang pembantu di Palu Sulawesi Tengah.

\section{Promosi}

Promosi merupakan kegiatan marketing mix yang terakhir. Suatu produk yang telah diciptakan kemudian harga telah ditetapkan serta lokasi atau tempat sudah ditentukan maka produk tersebut sudah siap untuk dipromosikan. Karena dengan melalui sarana promosi, masyarakat akan lebih tahu dan paham akan kehadiran yang telah diproses sedemikian rupa. Promosi biasanya terdiri dari manfaat, harga, dimana didapatkan, karakteristik dari produk sampai dengan kelebihan-kelebihan yang dimiliki oleh produk kita dengan tujuan sebagai pembeda terhadap produk yang serupa lainnya (Kasmir, 2008:156).

Promosi adalah suatu komunikasi dari penjual dan pembeli yang berasal dari informasi yang tepat yang bertujuan untuk merubah sikap dan tingkah laku pembeli yang tadinya tidak mengenal menjadi mengenal sehingga menjadi pembeli dan tetap mengingat produk tersebut (Fajar Laksana, 2008:133). Dengan kata lain bahwa promosi merupakan 
Volume 02 Nomor 012020 : page 16-33

p-ISSN: 2686-262X e-ISSN : 2685-9300

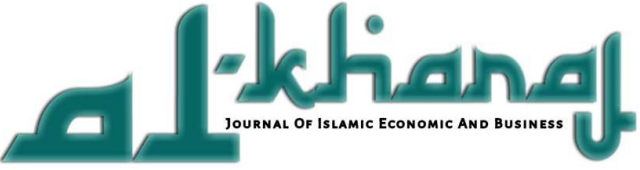

DOI : 10.24256

suatu kegiatan yang menawarkan dan memberikan deskripsi barang atau jasa yang ditawarkan dengan tujuan supaya calon pembeli tertari $\mathrm{k}$ atau berminat terhadap produk yang ditawarkan.

Barang atau jasa yang telah diperkenalkan atau dipasarkan ke masyarakat konsumen melalui promosi bertujuan memberikan infiormasi, memengaruhi dan mengingatkan kembali (Indriyo, 2000:237). Iklan, promosi penjualan (sales promotion), penjualan pribadi (personal selling) ketiga hal ini menjadi bentuk promosi yang dilakukan oleh perusahaan dalam memperkenalkan barang dan jasanya yang ditawarkan.

Periklanan jenis promosi yang paling banyak dilakukan oleh perusahaan untuk membujuk atau memengaruhi masyarakat, memberikan kesan dan memuaskan keinginan serta menjadi alat komunikasi jitu menggaet nasabah. Sedangkan model promosi penjualan dalam menarik pembeli secara langsung terjun ke masyarakat karena targetnya meningkatkan pendapatan jangka pendek dan melindungi citra perusahaan. Promosi melalui penjualan pribadi menjadi pilihan bank ditengah kompetitor yang sama. Oleh karena itu, bank dapat langsung muka dengan nasabah atau calon nasabah sehingga dapat langsung menjelaskan tentang produk bank ke nasabah secara rinci. Bank secara langsung mendapatkan informasi dari nasabah tentag kelemahan produk yang langsung dari nasabah dan petugas bank dapat memengaruhi nasabah dengan berbagai argument yang dimiliki dan secara tidak langsung terjalin hubungan keakraban antara bank dan nasabah.

Promosi menjadi sorotan utama dalam ekonomi Islam karena era digital ini, pelaku usaha mempromosikan produknya dengan memberikan imajinasi yang tinggi sehingga hasilnya terkadang barang yang ditawarkan tidak sesuai atau berbeda jauh dengan wujud barangnya. Regulasi ekonomi Islam menjadikan dasar kejujura dan tidak menyembunyikan cacat produknya, tidak memasukkan unsur sumpah palsu dalam promosinya, serta tidak menjelek-jelekkan produk saingannya. 
Volume 02 Nomor 012020 : page 16-33

p-ISSN: 2686-262X e-ISSN : 2685-9300

DOI : 10.24256

\section{Kualitas Layanan}

Kualitas merupakan suatu kondisi dinamis yang berhubungan dengan produk, jasa, manusia, proses dan lingkungan yang memenuhi atau melebihi harapan (Muhtosim Arief, 2006:117). Kualitas layanan yang baik mempunyai imbal yang positif dan kepercayaan yang tinggi baik kepada nasabah maupun calon nasabah. Dalam dasarnya pemberian yang positif dan yang maksimal dalam menjawab sebuah keinginan dan dapat terwujud dan dirasakan dengan puas oleh orang yang menerima pelayanan.

Jika jasa yang diterima atau dirasakan (perceived service) sesuai dengan yang diharapkan, maka kualitas pelayanan dipersepsikan baik dan memuaskan, jika jasa yang diterima melampaui harapan konsumen, maka kualitas pelayanan dipersepsikan sangat baik dan berkualitas. Sebaliknya jika jasa yang diterima lebih rendah daripada yang diharapkan, maka kualitas pelayanan dipersepsikan buruk (Philip Kotler, 1996:578).

Prinsip kualitas pelayanan menurut Parasuman terdapat lima dimensi yakni:

1. Tangibles, atau bukti fisik yaitu kemampuan suatu perusahaan dalam menunjukan eksistensinya kepada pihak eksternal. Penampilan dan kemampuan sarana dan prasarana fisik perusahaan dan keadaan lingkungan sekitarnya adalah bukti nyata dari pelayanan yang diberikan oleh pemberi jasa, yang meliputi fasilitas fisik ( gedung, dan lain-lain), perlengkapan dan peralatan yang digunakan (teknologi), serta penampilan pegawainnya.

2. Reliability, atau keandalan yaitu kemampuan organisasi untuk memberikan pelayanan sesuai yang dijanjikan secara akurat dan terpercaya. Kinerja harus sesuai dengan harapan pelanggan yang berarti ketepatan waktu, pelayanan yang sama untuk semua pelanggan tanpa kesalahan, sikap yang simpatik, dan dengan akurasi yang tinggi.

3. Responsiveness, atau ketanggapan yaitu suatu kemampuan untuk membantu dan memberikan pelayanan yang cepat (responsive) dan tepat kepada pelanggan, dengan 
Volume 02 Nomor 012020 : page 16-33

p-ISSN: 2686-262X e-ISSN : 2685-9300

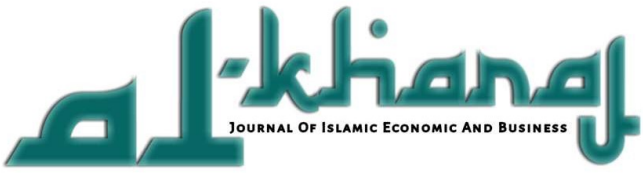

DOI : 10.24256

penyampaian informasi yang jelas. Membiarkan konsumen menunggu tanpa adanya suatu alasan yang jelas menyebabkan persepsi negative dalam kualitas pelayanan.

4. Assurance, atau jaminan dan kepastian yaitu pengetahuan kesopansantunan dan kemampuan para pegawai perusahaan untuk menumbuhkan rasa percaaya para pleanggan kepada perusahaan. Terdiri dari beberapa komponen antara lain, komunikasi kredibilitas, keamanan,kompeten dan sopan santun.

5. Empathy, atau empati yaitu memberikan perhatian yang tulus dan bersifat individual atau pribadi yang diberikan kepada para pelanggan dengan berupaya memahami keinginan konsumen. Dimana suatu perusahaan diharapkan memiliki pengertian dan pengetahuan tentang pelanggan, memahami kebutuhan pelanggan secara spesifik, serta memiliki waktu pengoperasian yang nyaman bagi pelanggan (Fandy Tjiptono dan Gregorius Chandra, 2005:132-153).

\section{Minat Menabung}

Minat menjadikan seseorang terpengaruh untuk berhubungan dengan suatu hal yang berada disekitarya, jik ia rupaka suatu hal yan positif dan kebahgiaan dan kecocokan untuknya kemungknan bisa saja dia akan berminat atau tertarik untuk mencoba kepada sesuatu yang ditawarkan atau dilihat.

Minat muncul apabila individu tertarik kepada sesuatu karena sesuai dengan kebutuhannya atau merasakan bahwa sesuatu yang akan dipelajari dirasakan bagi dirinya (Nigel C.Benson dan Simon Grove, 2000:110). Sedangkan dari segi bahasa minat berarti kecenderungan hati yang tinggi terhadap sesuatu, gairah dan keinginan. Dalam ensiklopedia umum disebutkan bahwa minat adalah kecenderungan bertingkah laku yang terarah pada obyek kegiatan atau pengalaman tertentu (Hasan Shadily, 1983:2252).

Menurut Abdur Rahman Saleh dan Muhbib Abdul Wahab (2004, 264-265) bahwa macam minat itu dapat dibagi tiga yakni: 
Volume 02 Nomor 012020 : page 16-33

p-ISSN: 2686-262X e-ISSN : 2685-9300

DOI : 10.24256

a. Berdasarkan timbulnya

Minat dapat dibedakan menjadi minat primitive dan minat kultural, yang mana Minat primitive adalah suatu minat timbul karena sebuah kebutuhan biologis atau jaringanjaringan tubuh. Sedangkan minat kultural bisa dikatakan sebagai minat sosial yaitu minat yang timbul karena proses belajar.

b. Berdasarkan Arahnya

Minat dapat dibedakan menjadi minat Intrinsik yaitu minat yang berhubungan langsung dengan aktivitas itu sendiri dan minat Ekstrinsik adalah minat yang berhubungan dengan tujuan akhir dari kegiatan tersebut.

c. Berdasarkan cara mengungkapkan misalnya Expressed Interest, Manifest Interest, Tested Interest dan Invetoried Interest.

Untuk pengukuran indikator minat dapat dilihat sebagai berikut:

a. Adanya perhatian dan kesadaran terhadap suatu benda atau objek.

Sesuatu yang kita curahkan perhatian pada suatu benda atau objek, maka kita akan menyadari benda itu sepenuhnya. Artinya pada saat itu hanya benda itulah yang paling kita sadari, sedangkan benda-benda lain disekitarnya banyak kita sadari, meskipun tingkat derajatnya tidak sama (M.Alisuf Sabri, 1993:43).

b. Adanya perasaan (biasanya perasaan senang)

Perasaan berkaitan erat dengan pengenalan, dijalani oleh setiap individu dengan rasa suka atau tidak suka, duka atau gembira dalam bermacam-macam gradasi atau derajat tingkatan (Kartini Kartono, 1997:129).

c. Adanya dorongan (Motivating Force)

Minat dikatakan sebagai sumber kekuatan dalam memotivasi seseorang dalam mendorong individu untuk mau dan melakukan dari apa yang mereka mau. 
Volume 02 Nomor 012020 : page 16-33

p-ISSN: 2686-262X e-ISSN : 2685-9300

DOI : 10.24256

d. Adanya Sikap

Perilaku merupakan cerminan dari seseorang yang dimana bisa dikatakan ia berminat maupun tidak pada suatu objek. Namun perilakunya bukan suatu sikap yang dipelajari dan dikembangkan dengan pengalaman yang di lakukan oleh individu.

\section{Metode Penelitian}

Kuantitatif sebagai pendekatan metode penelitian ini. Data yang diperoleh diolah untuk mendapatkan informasi dibalik angka-angka kemudian dideskripsikan dalam bentuk narasi. Data Dinas Kependudukan dan Perencanaan Sipil Kota Palu, Semester II, 2018 bahwa populasi dari objek masyarakat Kelurahan Siranindi berjumah 5.736 jiwa. Dan penarikan sampel dengan metode Slovin sebesar 98 dengan tingkat kesalahan 10\%. Kemudian data yang dikumpukan berasal data primer dan sekunder. Pengumpulan data primer dilakukan dengan memberikan angket, sedangkan data sekunder diperoleh berbagai sumber berupa dokumen.

Variabel dalam penelitian ini meliputi variable bebas yaitu promosi $\left(\mathrm{X}_{1}\right)$ dan kualitas layanan $\left(\mathrm{X}_{2}\right)$ dan variabel terikat yakni menabung $(\mathrm{Y})$. Variabel tersebut dianalisis dengan uji validitas melalui SPSS dengan $r$ hitung $>$ dari $r$ tabel dengan taraf signifikansi $\alpha=0.05$ dan realibe uji statistic Cronbach Aplha dengan nilai $>0.60$, serta melakukan uji asumsi klasik dan regresi berganda. Teknik pengumpulan datanya dilakukan dengan observasi, wawancara, kuisioner dan dokumentasi..

\section{Hasil Penelitian dan Pembahasan}

1. Uji Validitas dan Reliabilitas

Berdasarkan angket, data yang diperoleh dari 98 responden dinyatakan valid atas penyataan yang diajukan. Hasil analisa uji reliabilitas dengan menggunakan standar alfa cronbach, diperoleh koefisien kehandalan promosi sebesar $(\mathrm{p})=0,65$, kualitas layanan $(p)=0,656$ dan minat menabung sebesar $(p)=0,643$. 
Volume 02 Nomor 012020 : page 16-33

p-ISSN: 2686-262X e-ISSN : 2685-9300

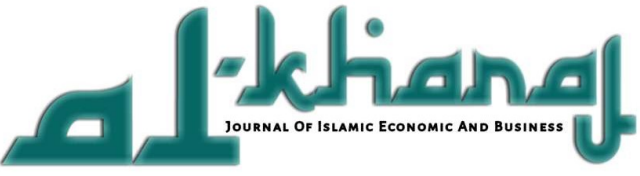

DOI : 10.24256

2. Uji Asumsi Klasik

Uji asumsi klasik dilakukan untuk memenuhi persyaratan statistik sebelum keuji regresi berganda maupun uji hipotesis. Pegujian pertama dengan menggunakan Kolmogorov Smirnov Test dalam uji normalitas nili sebesar 0.606 menunjukkan terjadinya distribusi normal. Kedua pengujian multikoloneritas didapatkan Tolerance dan Variance Inflation Factor dibawah 0,10. Nilai tolarance pada variabel promosi $\left(\mathrm{X}_{1}\right)$ 0,765 dan minat menabung $\left(\mathrm{X}_{2}\right)$ 0.749. dan VIF menunjukkan kurang dari 10 maka dinyatakan multikolonearitas. Ketiga uji Heterokedastisitas dengan grafik scatterplot menunjukkan cenderung menyebar dan tidak berpola ataupun berbentuk dengan beraturan, sehingga dikatakan tidak terjadi heterokedastisitas.

3. Uji Regresi Berganda

Persamaan regresi berganda $\mathrm{Y}=\beta \mathrm{o}+\beta 1 \mathrm{X} 1+\beta 2 \mathrm{X} 2+\mathrm{e}$, hasilnya $\mathrm{Y}=-2.717+$ $0.018 \mathrm{X} 1+0.386 \mathrm{X} 2+e$. Persamaan ini menujukkan bahwa kedua variabel (Promosi dan Kualitas Layanan) memiliki arah positif terhadap variabel minat menabug.

\section{Uji Hipotesis}

Langkah uji Hipotesis pertama uji Simutan (Uji F) dimana variabel independen (X) memberikan kontribusi secara simultan terhadap variable dependen (Y). Berdasarkan hasil uji Anova (Analysis Of varians) atau $\mathrm{F}_{\text {test }}$ diketahui bahwa nilai signifikansi untuk pengaruh promosi, fasilitas, dan kualitas pelayanansecara simultan terhadap minat sebesar $0.000<$ 0.05 dan nilai Fhitung $25.496>\mathrm{F}_{\text {tabel }}$ yaitu 2.70, sehingga disimpulkan bahwa hipotesis diterima yang dimana terdapat pengaruh yang signifikan dari variabel Promosi dan Kualitas Pelayanan secara signifikan terhadap Minat Menabung ( H0 ditolak).

\section{Pembahasan}

1. Pengaruh Promosi terhadap Minat Menabung Masyarakat Keluarahan Siranindi Di BMI Cab Palu 
Volume 02 Nomor 012020 : page 16-33

p-ISSN: 2686-262X e-ISSN : 2685-9300

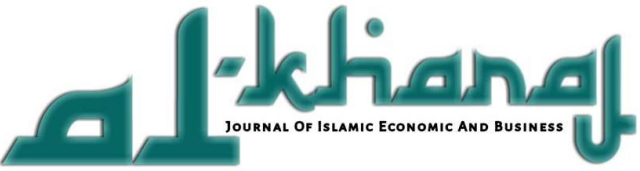

DOI : 10.24256

Promosi merupakan bagian dari bauran pemasaran, promosi bertujuan untuk sebagaimana sesuatu yang dipromosikan agar bisa terkenal dan diketahui. Berdasarkan hasil penelitian dengan melakukan pengujian menggunakan SPSS 16.0, didapatkan bahwa Promosi (X1) memperoleh thitung $0.253<$ ttabel 1,98 dan nilai signifikansi (sig) 0.801 lebih besar dari nilai a 0.05 . artinya $0.801>0.05$. dengan ini menunjukkan bahwa variabel promosi berpengaruh tidak signifikan terhadap Minat menabung.

Hal ini mengindikasikan bahwa promosi yang dilakukan oleh pihak bank belum tercapai maksimal untuk menimbulkan minat masyarakat dengan alasan iklan yang kurang menarik, promosi penjualan yang kurang baik, publisitas yang kurang gencar dilakukan, dan cenderung kurang intensitas promosi yang dilakukan oleh BMI secara kelembagaan, sehingga disimpulkan variabel promosi terhadap minat menabung masyarakat cenderung lemah. Masalah dari sekian indikator promosi yang timbul, tak lepas masyarakat dalam menyatakan bahwa minat atau tidaknya dari promosi yang dilakukan, faktor kepercayaan dan suka sama suka dapat dijadikan sebagai perhatian dalam meningkatkan kualitas promosi yang dilakukan.

Kenyataan yang terdapat dalam masyarakat bahwa yang membuat minat menabug di BMI Cab Palu karena landasan reigiusitas dan adanya antaradhin min kum yakni saling ridho dalam bertransaksi atau bermuamalah antara pihak bank dan calon nasabah. Antaradhin min kum yang muncul dikarenakan ikatan religiusitas melekat pada label bank dan nilai agama yang dianut oleh masyarakat Siranindi itu sendiri. Nilai agama yang memberikan beberapa pedoman misalnya transaksi yang mengandung unsur riba merupakan perbuatan yang dilarang oleh Allah swt., perbuatan transaksi yang terdapat unsur gharar juga termasuk kategori yang distorsi pasar yang dilarang. Nilai antaradhin min kum-lah menjadi modal utama bagi perkembangan jumlah nasabah BMI di Palu. 
Volume 02 Nomor 012020 : page 16-33

p-ISSN: 2686-262X e-ISSN : 2685-9300

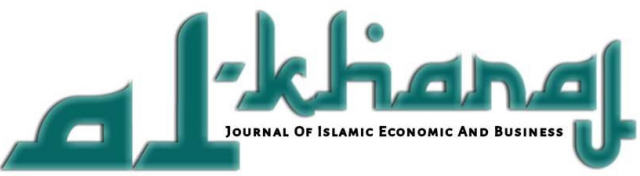

DOI : 10.24256

Konteks promosi yang dilakukan lembaga keuangan termasuk BMI harus berpegang teguh pada nilai yang dianutnya yakni promosi sesuai dengan syariah. Ekonomi Islam secara jelas mendeskripsikan aturan-aturan tentang promosi dalam menggaet seseorang untuk berminat terhadap barang atau jasa yang ditawarkan termasuk mempromosikan produk jasa bank kepada calon nasabah bank.

Aturan transaksi muamalah antara bank dan calon atau nasabah bank harus sesuai dengan regulasi ekonomi Islam. Pengaruh promosi BMI terhadap minat menabung masyarakat Kelurahan Siranindi perspektif ekonomi syariah:

a. Transaksi tersebut harus saling ridho semua pihak.

Transaksi antara pihak bank dan calon nasabah atau sudah menjadi nasabah harus ada unsur ridho, saling merelakan, mengikhlaskan dengan ketulusan akad tersebut tanpa adanya paksaan atau terpaksa. Dengan kata lain adanya rasa suka akan produk jasa yang ditawarkan, karena jika ada salah satu pihak merasa terpaksa maka dengan sendirinya transaksi tersebut batal dengan sendirinya. Sebagaimana firman Allah Q.S. An-Nisa (4):29

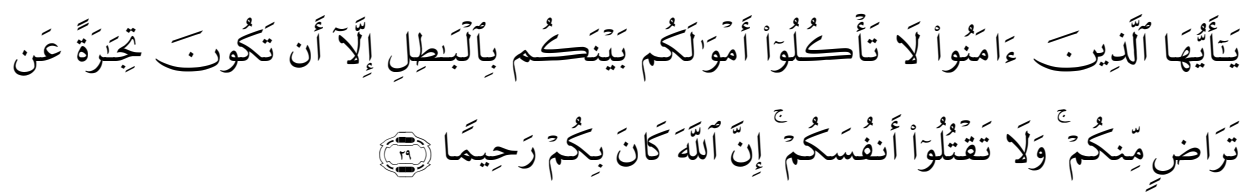

Terjemahnya :

Hai orang-orang yang beriman, janganlah kamu saling memakan harta sesamamu dengan jalan yang batil, kecuali dengan jalan perniagaan yang berlaku dengan suka sama-suka di antara kamu. dan janganlah kamu membunuh dirimu, sesungguhnya Allah adalah Maha Penyayang kepadamu. 
Volume 02 Nomor 012020 : page 16-33

p-ISSN: 2686-262X e-ISSN : 2685-9300

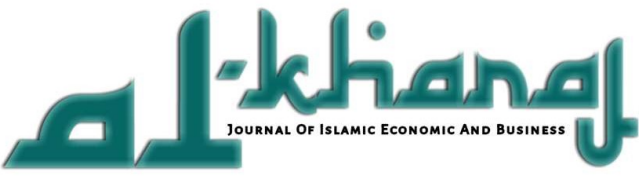

DOI : 10.24256

Demikian hasil lapangan penelitian bahwa nasabah yang menabung di BMI tidak terlalu berpengaruh terhadap adanya promosi, akan tetapi karena adanya rasa suka, saling ridhan karena landasan nilai agama yang dimiliki sehingga menarik untuk menabung di BMI Cab Palu. Minat nasabah menabung di BMI karena mereka percaya akan ketetapan Allah swt. untuk bertransaksi yang sesuai syariah. Salah satunya meninggalkan sistem bunga yang teah ditetapkan oleh MUI bahwa bunga bank termasuk transaksi yang diharamkan.

b. Tidak boleh ada unsur Kazab (Dusta)

Cenderung kurangnya promosi BMI Cab Palu mengindikasikan dapat mengurangi bahkan meniadakan kazab dalam transaksisnya. Namun bukan berarti banyaknya promosi menandakan adanya kazab. Maksudnya bahwa persaingan promosi penawaran bank terhadap masyarakat dengan iming-iming mendapatkan keutungan yang banyak sangat riskan terutama masyarakat menabung dananya di bank.

Kondisi ekonomi saat ini dengan menggunakan nilai mata uang yang nilai ekstrinsiknya jauh lebih besar dari nilai intrinsiknya menjadikan uang sangat terpengaruh adanya inflasi. Masyarakat menabung di bank dengan nilai uang hari ini, maka esok yang akan datang nilainya uangnya akan berkurang karena adanya inflasi. Oleh karena ini seyogyanya promosi menawarkan akan financial safety adanya rasa aman bila menyimpangnya di bank dibandingkan di rumah. QS. An-Nahl (16): 105

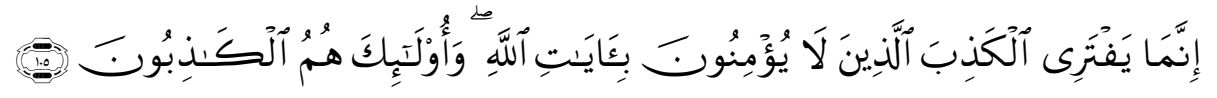

Terjemahnya:

Sesungguhnya yang mengada-adakan kebohongan, hanyalah orang-orang yang tidak beriman kepada ayat-ayat Allah, dan mereka Itulah orang-orang pendusta. 
2. Pengaruh Kualitas Pelayanan terhadap Minat Menabung Masyarakat Kelurahan Siranindi Di BMI Cab Palu

Berdasarkan hasil uji data yang dilakukan menggunakan SPSS 16.0 diperoleh thitung $7.535>\mathrm{t}$ tabel 1,98 dan nilai signifikansi (sig) 0.000 lebih kecil dari nilai 0.05 . artinya $0.000<0.05$. dengan ini menunjukkan bahwa variabel kualitas pelayanan berpengaruh signifikan terhadap minat menabung.

Kualitas layanan di BMI Cab Palu dapat terlihat dukungan sumber daya insani melalui pelayanan (tangibles), keandalan (reliability) yang dimiliki dalam menyelesaikan sebuah pekerjaan daya tanggap yang tepat (responsivenes), jaminan yang ditawarkan dan disediakan untuk nasabah maupun calon nasabah (assurance), dan sumber daya yang memiliki rasa empati yang tinggi dalam memberikan layanan.

Identifikasi pelayanan maksimal yang diberikan oleh BMI kepada nasabah maupun calon nasabah sejalan dengan pelayanan prima Islami antara lain:

\section{a. Profesional (Fathanah)}

Bekerja dengan maksimal dan penuh komitmen serta kesungguhan menjadi bagian syarat layanan yang diberikan oleh BMI . Karena sifat profesionalisme membawa hasil

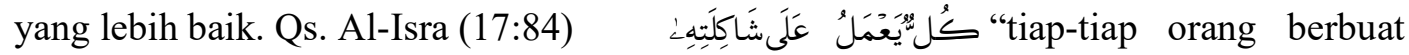
menurut keadaanya masing-masing”. Ayat ini bermakna bahwa setiap orang dalam melakukan sesuatu atau menerima tanggungjawab harus sesuai kompetensinya. Karena apabila ada sesuatu urusan yang bukan kompetesinya maka tunggulah kehancurannya atau kerugiaanya. Demikian pula kualitas layanan yang diberikan BMI Cab palu menjadikan syarat profesionalisme dan kompetensi bagi calon karyawannya.

b. Komunikatif dan argumentatif (Tabligh) 
Volume 02 Nomor 012020 : page 16-33

p-ISSN: 2686-262X e-ISSN : 2685-9300

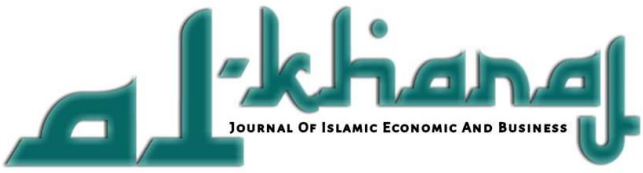

DOI : 10.24256

Hermawan dan Syakir Sula (2006:132) menjadikan indikator tabligh dalam memberikan layanan. Komunikatif dan argumentatif dalam menyampaikan informasi yang benar dan tutur kata yang tepat kepada konsumen/nasabah . Kesopanan dan keramahan dalam pelayanan ditegaskan dalam QS. Thahaa (20) : 44

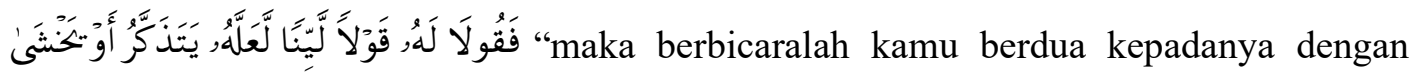
kata-kata yang lemah lembut mudah-mudahan ia ingat atau takut".

Indikasi ayat ini memerintahkan seseorang untuk berbicara dengan lemah lembut agar apa yang diutarakan dapat dipahami, dimengerti dan selalu diingat apa yang telah disampaikan. Sebagaimana pelayanan karyawan BMI kepada nasabah mulai dari luar (security) hingga ke dalam (teller, custumer services, dan lain-lain) akan menyapa dengan salam, memberikan senyuman, dan berbicara dengan lemah lembut. Komunikasi kepada nasabah yaang telah dilayani pun masih ditanyakan kebutuhan lainnya. Dengan kata lain, karyawan masih menawarkan bantuan kepada nasabah misalnya sebelum meninggalkan tempat di depan teller dengan kalimat "masih ada yang bisa kami bantu". Kalimat ini pertanda bentuk kerendahan hati untuk menolong kepada siapa pun.

c. Amanah

Amanah salah satu bentuk dalam melaksanakan tugas dan kewajiban. Terutama tindakan seseorang yang mengamanahkan dananya untuk disimpan, dikelola, dan diinvestasikan kembali oleh lembaga keuangan. BMI memegang erat prinsip amanah dengan menyimpan dana, mengelola, menginvestasikan dana nasabah sesuai aturan syariah. Penghimpunan dana dari masyarakat oleh BMI menggunakan akad wadiah addamanah maupun wadiah al-amanah, akad mudharabah, sedangkan penyaluran dana menggunakan mudharabah dan murabahah. Akad-akad tersebut sesuai rules ekonomi syariah. Sikap amanah BMI terhadap dana nasabah tidak hanya sebatas kemitraan nasabah akan tetapi bagian amanah (menjaga tanggungjawab) kepada Sang Khalik. Rasa 
Volume 02 Nomor 012020 : page 16-33

p-ISSN: 2686-262X e-ISSN : 2685-9300

DOI : 10.24256

khauf merupakan implikasi ketaqwaan kepada Allah swt. dan implementasi di BMI dengan mengelola dana nasabah ke industri halal.

Berdasarkan penjelasan di atas ketahui bahwa pengaruh promosi terhadap minat menabung masyarakat Siranindi berpengaruh tidak siginifikan sedangkan pengaruh kualitas layanan memiliki pengaruh signifikan terhadap minat menabung masyarakat Siranindi secara parsial. Namun ketika bersama (simultan) kedua variabel ini berpengaruh dan menjadi bagian terpenting dalam menjalankan operasional bank syariah. Oleh karena itu, BMI yang menjalanakn lembaga keuangan yang sangat tergantung terhadap dana serapan dari masyarakat dalam operasionalnya patut meperhatikan promosi ke masyarakat dan memberikan layanan terbaik kepada nasabah.

Efek perkembangan ekonomi yang sekarang menjadikan bank sebagai wadah terbaik menabung, menginvestasikan dan penunjang arus keuangan individu maupun kelembagaan. Menabung merupakan sesuatu yang dianrkan dalam Islam karena suatu perilaku yang mempersiapkan hari esok secara lebih baik. Qs. An-Nisa (4) : 9 jelas memberikan gambaran tersebut.

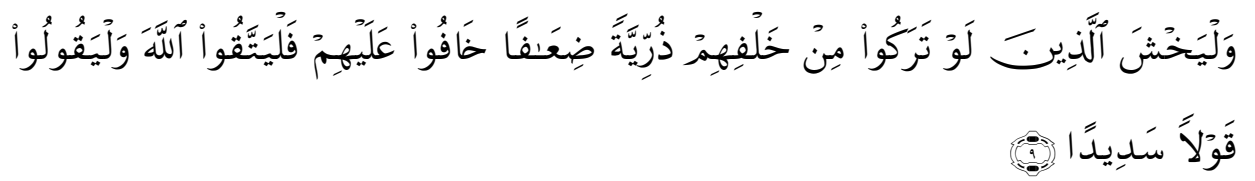

Terjemahnya:

"dan hendaklah takut kepada Allah orang-orang yang seandainya meninggalkan dibelakang mereka anak-anak yang lemah, yang mereka khawatir terhadap (kesejahteraan) mereka. oleh sebab itu hendaklah mereka bertakwa kepada Allah dan hendaklah mereka mengucapkan Perkataan yang benar."

Ayat ini jelas memberikan advice untuk mempersiapkan masa depan generasi secara matang termasuk kesejahteraan keuangannya. Orangtua tidak boleh mewariskan kemiskinan ke anak cucunya. Kemiskinan akan memberikan dampak buruk bagi 
Volume 02 Nomor 012020 : page 16-33

p-ISSN: 2686-262X e-ISSN : 2685-9300

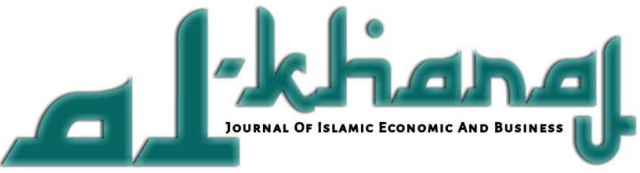

DOI : 10.24256

keimanan. Kemiskinan cenderung lebih dekat dengan kefukuran. Manuasia dapat dengan mdah mengadaikan keimanan demi terpuasnya kebutuan materi badaniahnya. Menabung salah sau alternatif mempersiapakan generasi falah.

Komplesitas anatar kepentingan tersebut menjadikan Bank mengambil keputusankeputusan pengembangan lembaga keuangannya lebih baik lagi termasuk mengencarkan promosi ke masyarakat dan memberikan layanan yang baik demi meraup minat menabung dan investasi masyarakat di bank .

\section{Simpulan}

Variabel Promosi secara parsial tidak berpengaruh signifikan terhadap minat menabung masyarakat, sebaliknya kualitas layanan yang diberikan kepada masyarakat oleh BMI memberi pengaruh signifikan secara parisal. Namun apabila keduanya yakni promosi dan kualitas layanan dipadukan, maka memberi pengaruh signifikan secara simultan. Masyarakat tidak terlalu perduli dengan promosi yang ada namun yang membuat minat menabung indikator antaradhin min kum berlandaskan nilai religiusitas yang dianut nasabah. Dasar religiusitas yang melandasi minat menabung di BMI Cab Palu dapat meningkatkan jumlah nasabah disertai loyalitas sebagai nasabah.

\section{Daftar Pustaka}

Aini, Zahratul. Pengaruh Produk-produk Bank BRI Syariah terhadap Minat Menabung Masyarakat Desa Aikmel Kabupaten Lombok Timur". Skripsi yang diterbitkan, (Mataram: Universitas Islam Negeri Mataram, 2017), http://eprints.universitasislamnegerimataram.ac.id, diakses tanggal 31 Januari 2019

Arief, Muhtosim. Pemasaran Jasa dan Kualitas Pelayanan. Cet.I; Malang: Bayu Media Publishing, 2006

Benson , Nigel C. dan Simon Grove, Mengenal Psikologi For Begineers, Cet.Ke -1 Bandung: Mizan,2000

Dinas Kependudukan dan Perencanaan Sipil Kota Palu, Semester II, 2018. 
Volume 02 Nomor 012020 : page 16-33

p-ISSN: 2686-262X e-ISSN : 2685-9300

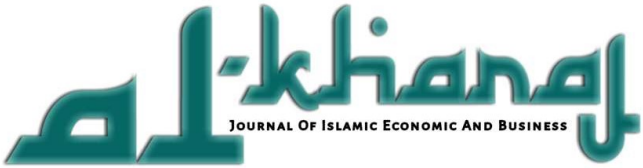

DOI : 10.24256

Gitosudarmo, Indriyo. Manjemen Pemasaran, Edisi Pertama. Cet.I; Yogyakarta: BPFE, 2000

Hafidudin, Didin dan Hendri Tanjung, Manajemen Pemasaran Syariah dalam Praktik. Cet.1; Jakarta: Gema Insani Inpress, 2003

Hidayat, Rachmat. "Pengaruh Kualitas Layanan, Kualitas Produk dan Nilai Nasabah Terhadap Kepuasan dan Loyalias Nasabah Bank Mandiri” Jurnal Manajeman dan Kewirausahaan. Vol.III, No.1, 2009

Kartajaya, Hermawan dan M. Syakir Sula, Syariah Marketing. Cet.1; Bandung: Mizan,2006

Kartono, Kartini . Psikologi Sosial. Cet.I; Jakarta: PT.Rajagrafindo,1997

Kasmir, Pemasaran Bank, Edisi revisi Cet.III ; Jakarta : Prenada Media Group,2008

Kementrian Agama RI, Syaamil Al-Qur'an dan Terjemahan. Cet.I; Bandung: Syaamil Cipta Media, 2005

Kotler, Philip. Priciples of Marketing (Prentice Hall Intrnational, Inc, 1996)

Laksana, Fajar. Manajemen Pemasaran. Cet.I; Yogyakarta: Graha Ilmu,2008.

Nugroho, Bambang Haryo. Kepala Cabang Bank Muamalat Indonesia Cabang Palu, Wawancara, Palu, 8 Maret 2019

Sabri, M.Alisuf. Pengantar Psikologi Umum dan Perkembangan. Cet.I; Jakarta: Pedoman Ilmu Jaya, 1993

Saleh, Abdul Rahman dan Muhbib Abdul Wahab, Psikologi Suatu Pengantar Dalam Perspektif Islam, Edisi I. Jakarta: Prenada Media, 2004

Shadily, Hasan Ensiklopedia Umum. Jakarta: Ichtia Barn-Van Hoeve,1983

Tjiptono, Fandy dan Gregorius Chandra, Service Quality and Satisfactio) Yogyakarta: Andi Offcet,2005 